\title{
Reproductive physiology of the heat-stressed dairy cow: implications for fertility and assisted reproduction
}

\author{
Peter J. Hansen* \\ Department of Animal Sciences, D. H. Barron Reproductive and Perinatal Biology Research Program and Genetics Institute, \\ University of Florida, Gainesville, Florida, USA.
}

\begin{abstract}
Heat stress causes a large decline in pregnancy success per insemination during warm times of the year. Improvements in fertility are possible by exploiting knowledge about how heat stress affects the reproductive process. The oocyte can be damaged by heat stress at the earliest stages of folliculogenesis and remains sensitive to heat stress in the peri-ovulatory period. Changes in oocyte quality due to heat stress are the result of altered patterns of folliculogenesis and, possibly, direct effects of elevated body temperature on the oocyte. While adverse effects of elevated temperature on the oocyte have been observed in vitro, local cooling of the ovary and protective effects of follicular fluid may limit these actions in vivo. Heat stress can also compromise fertilization rate. The first seven days of embryonic development are very susceptible to disruption by heat stress. During these seven days, the embryo undergoes a rapid change in sensitivity to heat stress from being very sensitive (2- to 4-cell stage) to largely resistant (by the morulae stage). Direct actions of elevated temperature on the embryo are likely to be an important mechanism for reduction in embryonic survival caused by heat stress. An effective way to avoid effects of heat stress on the oocyte, fertilization, and early embryo is to bypass the effects through embryo transfer because embryos are typically transferred into females after acquisition of thermal resistance. There may be some opportunity to mitigate effects of heat stress by feeding antioxidants or regulating the endocrine environment of the cow but neither approach has been reduced to practice. The best long-term solution to the problem of heat stress may be to increase genetic resistance of cows to heat stress. Thermotolerance genes exist within dairy breeds and additional genes can be introgressed from other breeds by traditional means or gene editing.
\end{abstract}

Keywords: heat stress, lactating cow, reproduction, fertility, embryo, oocyte.

\section{Introduction}

The overall reproductive function of a herd of dairy cows is often estimated by calculating pregnancy rate, i.e., the product of estrus detection rate (how many cows in estrus are detected in estrus by farm personnel) and conception rate (a misnomer but a measure of how many cows that are inseminated are diagnosed as pregnant). A pregnancy rate of $100 \%$ would mean that every cow eligible to be pregnant in a 21-day period becomes pregnant in that time. By this measure, the reproductive function of the heat-stressed dairy cow can be very low indeed. Data in Figure 1 illustrate how heat stress can affect characteristics of estrous activity; only $19 \%$ of estrus periods were detected by farm workers in the summer in one study in Florida (Thatcher et al., 1986). Fertility after artificial insemination (AI) can also be low during heat stress. In a survey of dairy herds in Israel, less than $20 \%$ of inseminations resulted in pregnancies in the summer and pregnancy per AI (P/AI) in the worst herds (those with milk low production and a moderate amount of cooling) was only 3\% (Fig. 2; Flamenbaum and Galon, 2010). In another study, P/AI at day 32 after insemination for lactating cows in Minais Gerais, Brazil was $17 \%$ when cows experienced two of more occurrences of a morning rectal temperature greater than $39.1^{\circ} \mathrm{C}$ at days $-3,-2,0$ and 7 relative to timed AI vs 25\% for cows with one occurrence and 37\% for cows with no occurrence (Pereira et al., 2013).

Fortunately, the situation is not always so bleak. For example, P/AI at day 36 after insemination for multiparous cows in Oklahoma and Kansas during hot weather was 25-27\% (Voelz et al., 2016). In a study in Florida, P/AI for multiparous cows in the summer on a free-stall dairy in Florida with fans and sprinkler was 32\% (Zolini et al., 2019). Higher pregnancy rates during heat stress can be ascribed to superior cooling systems and implementation of timed AI programs. Not only do protocols for timed AI eliminate the need for estrus detection but, for some protocols, they can increase cow fertility (Carvalho et al., 2018).

Further improvements in fertility during the summer are possible by exploiting knowledge about how heat stress affects the reproductive process. Here, the impact of heat stress on follicular development, oocyte quality, fertilization, and embryonic development will be briefly outlined and the consequences of those changes for strategies to improve fertility will be discussed. Since AI using frozen semen can bypass effects on the bull, and timed AI bypasses effects on estrus behavior, the focus will be on biological processes important for establishing a high level of fertility. Keep in mind that there are effects of heat stress after establishment of pregnancy, most notably in late gestation when heat stress can affect milk yield of the cow after calving and the epigenetic program, growth and milk yield of the resulting calf (Dahl et al., 2017; Skiebiel et al., 2018). However, this important aspect of actions of heat stress on the pregnant cow is beyond the scope of the current review. 

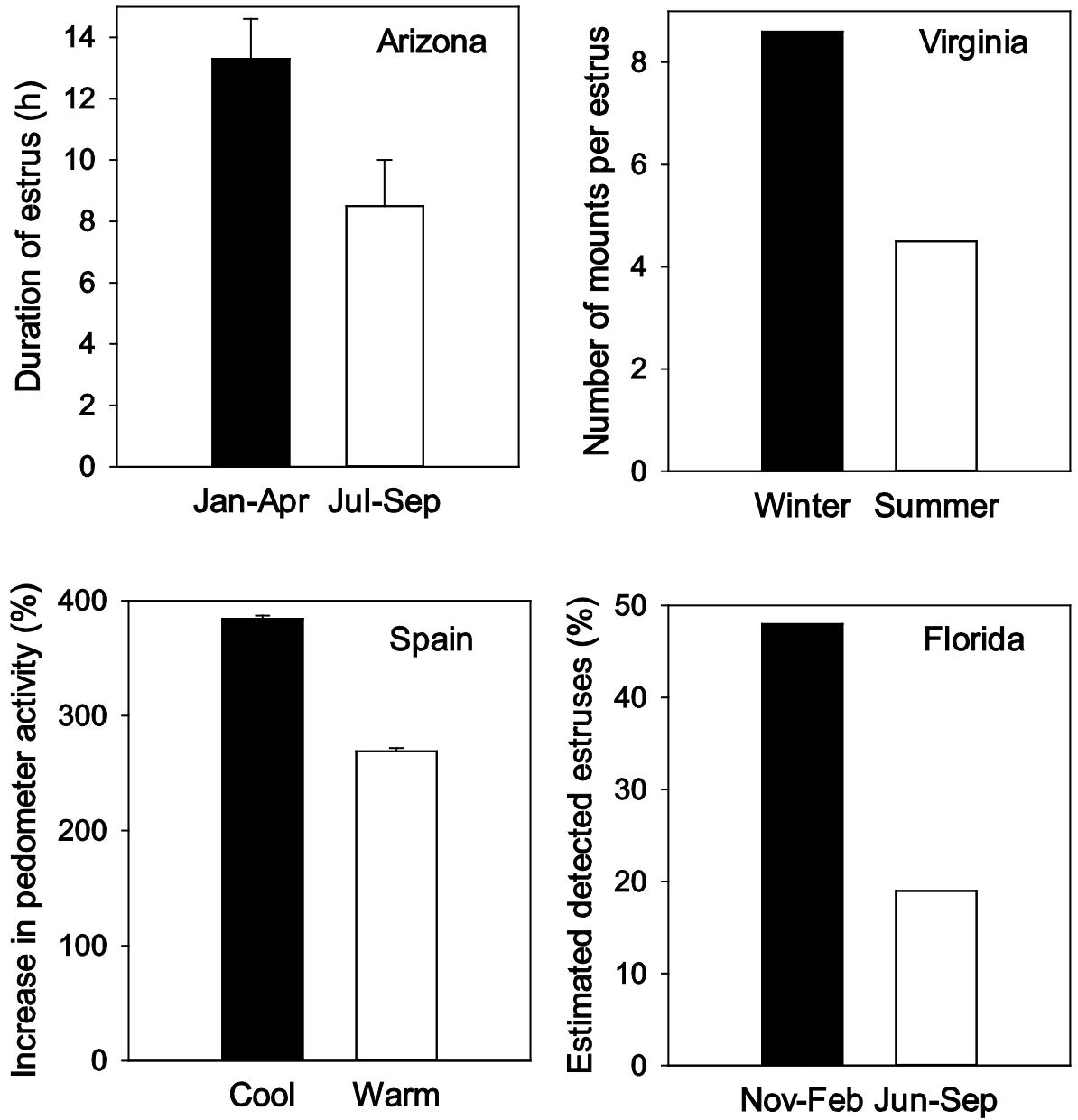

Figure 1. Seasonal variation in characteristics of estrus in lactating cows. Shown are data on duration of estrus in Arizona (Wolff and Monty, 1974), number of mounts per estrus in Virginia (Nebel et al., 1997), the increase in pedometer activity at estrus in Spain (López-Gatius et al., 2005a) and estimated percent of estrus periods detected by farm personnel in Florida (Thatcher et al., 1986). The figure is reproduced from Hansen (2017) with permission of the American Dairy Science Association.

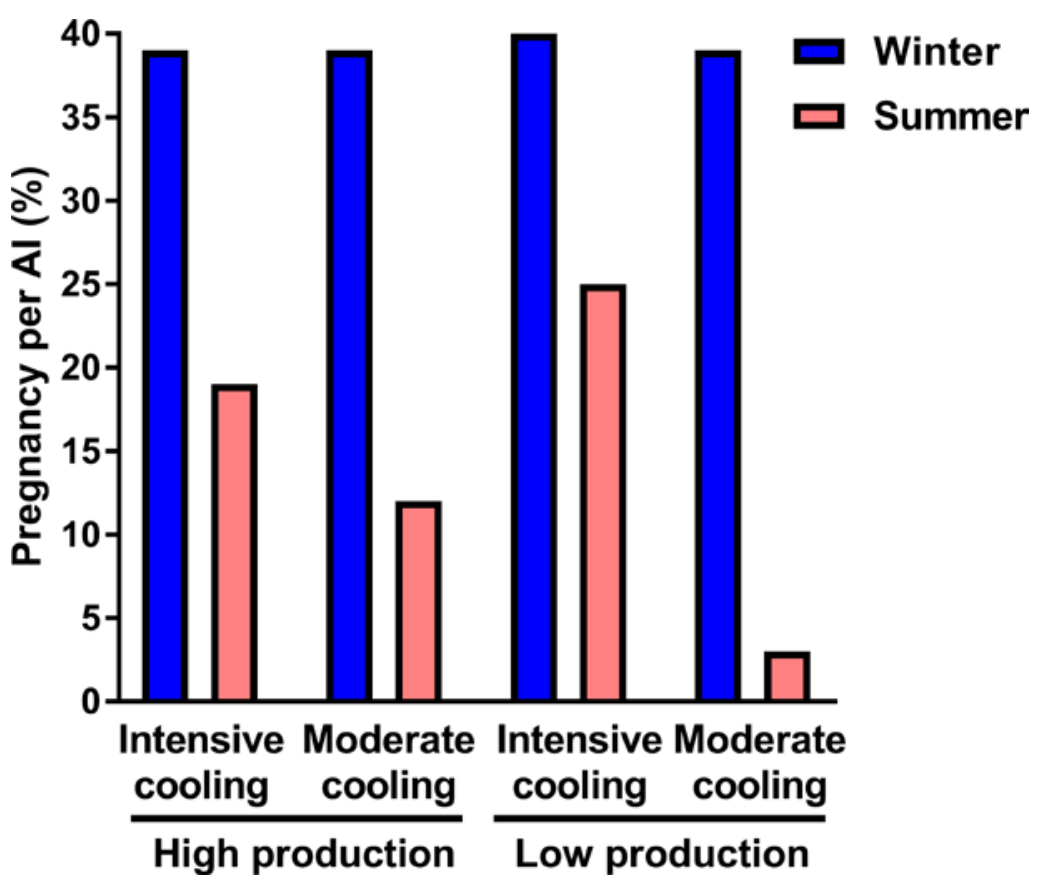

Figure 2. Pregnancies per artificial insemination of herds surveyed in Israel (Flamenbaum and Galon, 2010). Herds were classified based on the overall level of milk production (high vs low) and on the degree of cooling that cows receive (intensive $v s$ moderate). 


\section{Reproductive Events Susceptible to Heat Stress}

There have been attempts to reduce the impact of heat stress by cooling lactating cows for a limited period of time around ovulation, fertilization and early development but the improvement in fertility has been slight (Stott and Wiersma, 1976; Her et al., 1988; Ealy et al., 1994). This is because there is a broad window of time in which the reproductive process of the cow can be disrupted by heat stress. An experiment with Gir cattle indicates that heat stress can compromise development of the oocyte at the earliest stages of folliculogenesis. In particular, competence of oocytes to develop to the blastocyst stage after in vitro fertilization was reduced by heat stress occurring as early as 105 to 133 days before oocyte retrieval (Torres-Júnior et al., 2008). In an experiment with lactating Holsteins, secretion of androstenedione from cultured thecal cells and estradiol from cultured granulosa cells from medi,um-sized follicles was reduced by exposure of donor cows to heat stress 20 to 26 days earlier (Roth et al., 2001a). Additional evidence that heat stress affects the oocyte early in folliculogenesis are observations that oocyte competence for supporting embryonic development after in vitro activation was restored only gradually after the end of summer (see review by Hansen, 2013a; Roth, 2017). Moreover, treatments to increase follicular turnover, including multiple follicular aspirations (Roth et al., 2001b), follicle stimulating hormone (Roth et al., 2002) or somatotropin (Roth et al., 2002), hastened restoration of oocyte competence.

The oocyte remains sensitive to heat stress in the peri-ovulatory period. Treatment of superovulated cows with heat stress for 10 hours beginning at the onset of estrus reduced the percent of embryos recovered at day 7 after estrus that were classified as having normal morphology and increased the percent of embryos that were retarded with development (Putney et al., 1989a).

Heat stress can compromise fertilization rate (Sartori et al., 2002; Hackbart et al., 2010). For example, fertilization rate in lactating cows bred by AI was lowered from $88 \%$ in winter to $55 \%$ in summer (Sartori et al., 2002). Low fertilization rates could reflect damage to the oocyte, sperm deposited in the uterus, or disruption of the fertilization process itself. Effects on the sperm or fertilization process may be a more important cause than effects on the oocyte. Competence of the oocyte to be fertilized in vitro was not reduced in the summer although there was a reduction in development of cleaved embryos to the blastocyst stage (Ferreira et al., 2011). Further, indirect evidence for an effect of heat stress on the sperm is the observation of Girolando cows that insemination in the morning was associated with a slight but significant increase in P/AI (Rocha de Zouza et al., 2016).

The first 7 days of embryonic development are very susceptible to disruption by heat stress. Experimental treatment of superovulated cows with heat stress during this time reduced the development of embryos at day 7 (Putney et al, 1988a). Moreover, among single-ovulating lactating cows, there was a large reduction in the percent of recovered embryos classified as viable during periods of heat stress as compared to periods of no heat stress (Sartori et al., 2002). During these 7 days, the embryo undergoes a rapid change in sensitivity to heat stress. Exposure of superovulated cows to heat stress on day 1 after estrus reduced the percent of embryos that were blastocysts at day 8 (Ealy et al., 1993). However, heat stress at day 3, 5 or 7 had no effect on embryonic development. Thus, the resistance of the embryo to heat stress increases greatly in just a few days of development.

There is little known about sensitivity of the bovine embryo to heat stress after day 7 . There is one report in beef cattle that heat stress from day 8 to 16 can reduce conceptus weight at day 16 (Biggers et al., 1987). However, the effectiveness of embryo transfer as a tool for improving fertility during heat stress (see discussion further in this paper) is indicative that embryo survival is not dependent to any large extent on the occurrence of maternal heat stress after day 7 .

A proportion of cows initially diagnosed as pregnant around day 28-60 of pregnancy subsequently lose the pregnancy. There is some evidence that the frequency of this loss can be increased by heat stress (García-Ispierto et al., 2006; Santolaria et al., 2010; ElTarabany and El-Tarabany, 2015). For example, pregnancy loss between days 34 to 45 of gestation and day 90 of gestation were $2 \%$ for cows in the cool season vs $12 \%$ for cows in the warm season (García-Ispierto et al., 2006). Attempts have been made to understand the crucial period in the reproductive process during which heat stress acts to increase late embryonic and fetal mortality by relating indices of heat stress at specific phases in the reproductive process to pregnancy loss. Such an approach is difficult to decipher because environmental conditions at one period are often highly correlated with environmental conditions at another period.

\section{Physiological Causes of Effects of Heat Stress on the Oocyte and Embryo}

Effects of heat stress are related to the inability of the affected cow to maintain its body temperature within the regulated range. As mentioned, P/AI is related to rectal temperature (Pereira et al., 2013). It has been estimated that fertility begins to decline when uterine temperature rises about $0.5^{\circ} \mathrm{C}$ above normal (Gwazdauskas et al., 1973). One reason why lactating cows are more susceptible to the negative effects of heat stress on fertility than heifers (Badinga et al., 1985) is because the metabolic heat production associated with lactation makes it more difficult for cows to regulate body temperature during heat stress than non-lactating heifers (Sartori et al., 2002). Effects of heat stress on the ovary, oviduct, uterus, and embryo could result from either physiological changes caused by heat stress or by the direct effects of elevated temperature on cells involved in reproduction.

Alterations in oocyte quality due to heat stress probably involve deviations in patterns of folliculogenesis. Follicular dominance is reduced in cows exposed to heat stress so that there is an increase in number of large follicles on the ovary, prolonged 
period of dominance of the ovulatory follicle, increased circulating concentrations of follicle stimulating hormone (FSH) and reduced concentrations of estradiol$17 \beta$ and inhibin (Wolfenson et al., 1995; Roth et al., 2000; Trout et al., 1998; Wilson et al., 1998). Heat stress can also dampen the preovulatory surge of luteinizing hormone and estradiol-17 $\beta$ (Gwazdauskas et al., 1981; Gilad et al., 1993; Armengol-Gelonch et al., 2017). Indeed, heat stress can increase the proportion of cows that fail to ovulate after administration of GnRH. Ovulation failure was $12 \%$ during the warm period vs 3\% during the cool period (López-Gatius et al., 2005b). Use of more active analogs of gonadotropin releasing hormone $(\mathrm{GnRH})$ can reduce the incidence of ovulation failure (García-Ispierto et al., 2019).

There are direct effects of elevated temperature (i.e., heat shock) on the competence of the oocyte undergoing maturation to develop into a blastocyst following fertilization or artificial activation (see Roth, 2017 for review). Possible local cooling of the ovary and protective effects of follicular fluid may limit these actions in vivo. Work by López-Gatius and Hunter (2017, 2019a,b) has revealed that the ovary experiences a cooler temperature than that measured in the rectum or on the surface of the uterus. Additionally, culture of maturing oocytes in a medium containing follicular fluid or follicular fluid exosomes reduced the negative effect of elevated temperature on oocyte competence for cleavage and blastocyst development after fertilization (Rodrigues et al., 2019). Direct effects of elevated temperature on the follicle may be important in some circumstances, however. Cows in which follicular temperature was lower than rectal temperature were more likely to ovulate and achieve pregnancy than cows in which the gradient between follicular and rectal temperature was low (López-Gatius and Hunter, 2019ab).

Direct actions of elevated temperature on the embryo are likely to be an important mechanism for reduction in embryonic survival caused by heat stress after ovulation. Indeed, the changes in embryonic resistance to maternal heat stress observed in vivo (Ealy et al., 1993) are also seen with effects of heat shock on cultured embryos. Exposure of the zygote and 2-cell embryo causes a large reduction in percent of embryos developing to the blastocyst stage (Edwards and Hansen, 1997; Sakatani et al., 2012; Ortega et al., 2016). Embryos at the 4- and 8-cell stage are also susceptible to heat shock but the magnitude of the deleterious effect is reduced as compared to that for the 2-cell embryo (Edwards and Hansen, 1997). Physiologically-relevant heat shock has little effect on development of morulastage embryos (Edwards and Hansen, 1997; Eberhardt et al., 2009; Sakatani et al., 2012). Mechanisms responsible for acquisition of thermotolerance are not known but probably involve activation of the embryonic genome at the 8-cell stage (Graf et al., 2014) so that the full range of cellular adaptations to heat shock can be employed.

It is also possible that changes in circulating concentrations of steroid hormones induced by heat stress could alter the oviductal or uterine environment and thereby affect embryonic development. As stated previously, heat stress can reduce plasma concentrations of estradiol-17 (Gwazdauskas et al., 1981; Wolfenson et al., 1995; Wilson et al., 1998). Short-term exposure to heat stress either had no effect on plasma concentrations of progesterone (Roth et al., 2000) or caused an increase (Trout et al., 1998; Wilson et al., 1998). Long-term exposure to heat stress may lead to reduced progesterone concentrations, however, because luteal concentrations of the hormone during the luteal phase have been reported to be lower in summer than winter (Howell et al., 1994). Additionally, cooling cows during the summer increased circulating concentrations of progesterone (Wolfenson et al., 1988). Some effects of heat stress on peripheral blood concentrations of hormones could be the result of changes in water balance during heat stress and reduced hematocrit (Richards, 1985; Lamp et al., 2015).

\section{Embryo Transfer: The Most Effective Mechanism for Maximizing Fertility During Heat Stress}

One way to avoid consequences of heat stress on the oocyte, fertilization, and early embryo is to bypass its effects through implementation of an embryo transfer program. Embryos are typically transferred into females at day 7 after estrus. By that time, embryos have gained resistance to effects of heat stress. Embryo transfer can be coupled with ovulation synchronization programs to allow timed embryo transfer and avoid the need for estrus detection.

One way to demonstrate the effectiveness of embryo transfer for improving fertility during heat stress is to compare pregnancy outcomes for embryo transfer as compared to AI. As summarized in Figure 3, pregnancy rates during heat stress have been consistently higher for cows receiving an embryo than for cows submitted to AI. The only exception is when embryos were produced in vitro and cryopreserved before transfer. Thus, there was either no improvement in fertility as compared to AI when vitrified embryos produced in vitro were transferred (Drost et al., 1999; Fig. 3B) or the improvement was less than if fresh embryos were transferred (Stewart et al., 2011; Fig. 3C). These results are the consequence of poor cryopreservation of in vitro produced embryos (Hansen and Block, 2004).

Another way to demonstrate how embryo transfer reduces the impact of heat stress is to examine seasonal variation in pregnancy success after embryo transfer. Of eight studies in which seasonal variation in pregnancy rates were evaluated, there were only two cases where there was a large difference in pregnancy rate between hot and cool conditions including an experiment in Florida with fresh embryos produced in vitro (Block et al., 2007; Fig. 4B) and an experiment in South Dakota with vitrified embryos produced in vitro (Chebel et al., 2008; Fig. 4C). There was no difference between seasons for embryos produced by superovulation in the southwest United States (Putney et al., 1988b; Fig. 4A) or for fresh embryos produced in vitro in Florida (Loureiro et al., 2009; Fig. 4B) or South Dakota (Chebel et al., 2008; Fig. 4C). In the largest trials, there was a slight reduction in pregnancy per 
embryo transfer in the hottest months (Ferraz et al., 2016; Vasconcelos et al., 2011; Baruselli et al., 2011) but the difference in pregnancy outcomes between the coolest and warmest times were only 3 to $4 \%$ (Fig. 4C, $4 \mathrm{E}$ and $4 \mathrm{~F})$. Seasonal variation of that magnitude is much less than what would be the case for AI.
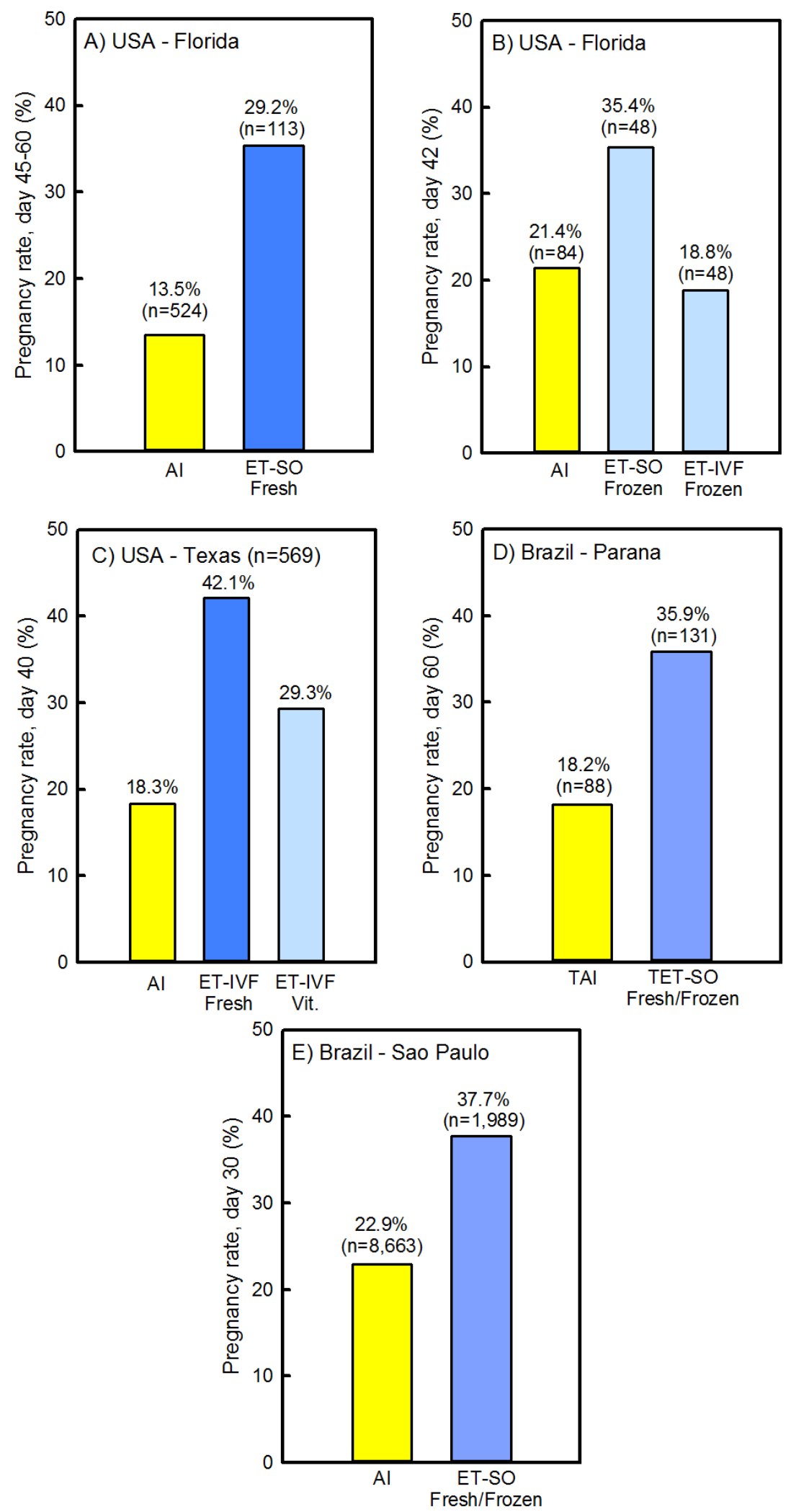

Figure 3. Comparisons of pregnancy success for artificial insemination vs embryo transfer in the summer. Data are from Putney et al. (1989b) (A), Drost et al. (1999) (B), Stewart et al. (2011) (C), Vasconcelos et al. (2011) (D) and Baruselli et al. (2011) (E). Abbreviations are as follows: AI, artificial insemination, ET, embryo transfer; IVF, in vitro fertilized; SO, superovulation; TAI, timed AI; TET, timed embryo transfer; Vit., vitrified. The figure is modified from a technical bulletin by Vetoquinol and is reproduced with permission. 

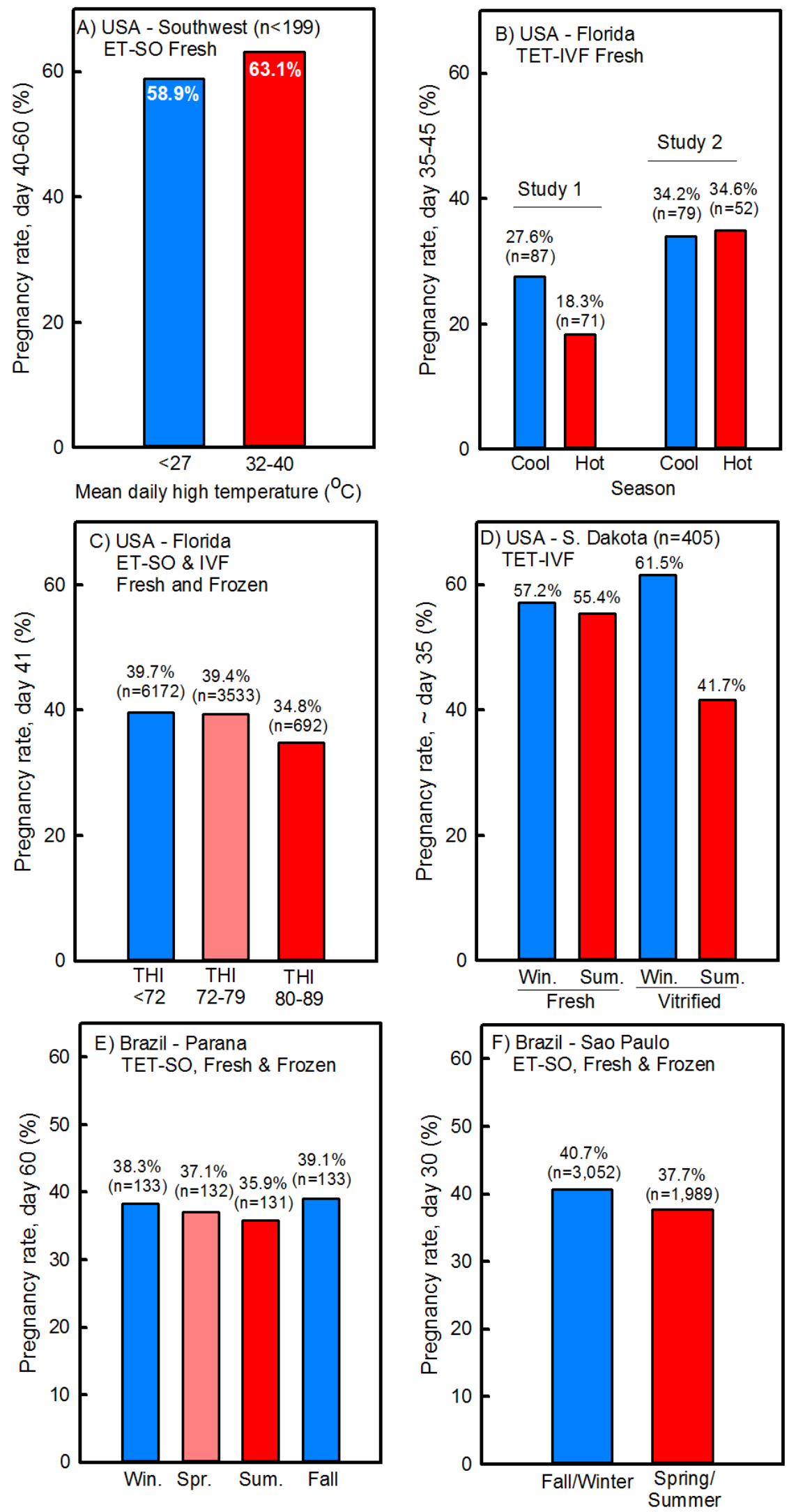

Figure 4. Comparisons of percent cows pregnant following embryo transfer in cool or hot weather. Data are from Putney et al. (1988b) (A), Block et al. (2007) and Loureiro et al. (2009) (B), Ferraz et al. (2016) (C), Chebel et al. (2008) (D), Vasconcelos et al. (2011) (E) and Baruselli et al. (2011) (F). Abbreviations are as follows: ET, embryo transfer; IVF, in vitro fertilized; S. Dakota, South Dakota; Spr., spring; SO, superovulation; Sum., summer; TET, timed embryo transfer; THI, temperature-humidity index; Win., winter. The figure is modified from a technical bulletin by Vetoquinol and is reproduced with permission. 


\section{Antioxidants}

Exposure to elevated temperature can increase production of reaction oxygen species in oocytes (Nabenishi et al., 2012; Cavallari de Castro et al., 2019) and embryos (Sakatani et al., 2004; Sakatani et al., 2008; Ortega et al., 2016). In vitro, effects of heat shock on oocyte maturation can be reduced by provision of antioxidants (Lawrence et al., 2004; Nabenishi et al., 2012; Ispada et al., 2018; Cavallari de Castro et al., 2019). In the embryo, however, thermoprotective benefits of antioxidants in vitro have been inconsistent. There was no protective effect of dithiothreitol, glutathione, melatonin, taurine, or vitamin E (Ealy et al., 1995; Paula-Lopes et al., 2003a; de Castro et al., 2008; Ortega et al., 2016) but $\beta$-mercaptoethanol was protective (Sakatani et al., 2008). One interpretation of these data is that reactive oxygen species are a more important mediator of the embryotoxic actions of heat shock for the oocyte than the embryo.

Efforts to improve fertility of lactating cows exposed to heat stress by delivering antioxidants have generally not yielded positive effects (see review by Hansen, 2013b and Roth, 2017). There are two reports of beneficial effects of antioxidant administration, however. In the first, Aréchiga et al. (1998) found that a higher proportion of cows fed supplemental $\beta$-carotene from about day 15 after calving were pregnant at $90 \mathrm{~d}$ postpartum than control cows when the experiment was performed during the summer but not when the experiment was performed during the winter. Feeding supplemental $\beta$-carotene did not increase pregnancy per AI at first service so the effect on the proportion pregnant at $90 \mathrm{~d}$ reflects either alterations in fertility after first service or estrus detection. In the second report, administration of long-acting melatonin implants beginning at $220 \mathrm{~d}$ of gestation to cows during the summer shortened the interval to conception in the subsequent postpartum period and decreased the incidence of cows experiencing $>3$ breedings per conception (García-Ispierto et al., 2013). The peak concentration of melatonin in the blood of cows receiving implants was low (i..e, 260-300 pM) and it might be that melatonin was acting as a hormone rather than as an antioxidant. Further studies are needed with both $\beta$-carotene and melatonin to evaluate efficacy of their administration for improving fertility during heat stress.

\section{Hormonal Treatments}

Much work continues on optimization of timed AI protocols in general and under the specific conditions of heat stress. Few studies have been performed to compare whether a specific improvement in a timed AI protocol works better for heat-stressed cows than cows not subjected to heat stress. One exception is for induction of ovulation. As already discussed, ovulation failure is more frequent during periods of heat stress and administration of more active analogs of GnRH can reduce the incidence of ovulation failure (García-Ispierto et al., 2019). In another study, Shabankareh et al. (2010) evaluated the summer-winter differences in P/AI at first service for cows bred at spontaneous estrus or following timed AI using either GnRH (Ovsynch) or estradiol cypionate (Heatsynch) to induce ovulation. There was no difference in P/AI (32, 30 and $30 \%$ for OvSynch, Heatsynch and spontaneous estrus) in the summer while P/AI in the winter was highest for spontaneous estrus (51\%), intermediate in Ovsynch (40\%) and lowest for Heatsynch (35\%).

Several experiments have been conducted to evaluate effects of increasing circulating progesterone concentrations on fertility of heat-stressed cows. Results have been inconsistent and often dependent on the subset of cows treated. Administration of progesterone using a CIDR device from day 5 to 18 after insemination did not cause an overall increase in P/AI but there were positive effects of the treatment in cows with low body condition or postpartum uterine disorders (Friedman et al., 2012). In the study of Shabankareh et al. (2010), treatment with human chorionic gonadotropin (hCG) on day 5 after insemination increased P/AI in both summer (24 vs 38\% for saline and hCG) and winter (35 vs 47\%). Treatment with hCG at day 5 also increased pregnancy rate in cows during summer but the effect was seen only for primiparous cows (Zolini et al., 2019). Treatment with GnRH at AI or at both AI and day 12 of the estrous cycle increased P/AI in an experiment by López-Gatius et al. (2005c). In another research trial, there was no beneficial effect of treatment at day 0 on P/AI whereas treatment with GnRH at either day 5 or both day 0 and 5 increased P/AI but only for cows in third or greater lactation (Mendonça et al., 2017).

The idea that ovarian follicles can be compromised by heat stress at early stages of folliculogenesis has lead to the idea that fertility can be improved in the autumn by hastening the removal of damaged follicles from the ovary. Improved oocyte competence in the autumn, as measured by in vitro development to the blastocyst stage, has been achieved using several treatments to increase follicular turnover, including multiple follicular aspirations (Roth et al., 2001b) or treatment with FSH (Roth et al., 2002) or somatotropin (Roth et al., 2002). In addition, generation of three consecutive 9-day follicular waves by treatment with $\mathrm{GnRH}$ and prostaglandin $\mathrm{F}_{2 \alpha}$ has been reported to have some positive effects on fertility of lactating cows in the summer and autumn (Friedman et al., 2011). Treatment effects were seen for primiparous cows (37\% vs 53\% for control and treated cows) but not for multiparous cows (27 vs 29\%).

\section{Genetic Selection}

Heritability estimates in Holsteins for body temperature during heat stress is 0.17 (Dikmen et al., 2012) and for the decline in milk yield during heat stress is 0.19 (Nguyen et al., 2016). Thus, it should be possible to reduce the impact of heat stress on reproduction by selecting genetically for thermoregulation. Data from Australia indicate that cows that are more thermotolerant genetically also have higher breeding values for fertility (Nguyen et al., 
2016). Unfortunately, they also have a lower genetic ability for milk yield so genetic strategies must be developed to allow selection for genes that confer superior thermotolerance without compromising milk yield.

One option is to introgress genes from thermotolerant breeds into dairy breeds using crossbreeding or gene editing. The prolactin receptor gene is one gene that has been mutated in a manner that leads to a slick hair phenotype characterized by a sleek, short hair coat and increased capacity for regulating body temperature (Dikmen et al., 2014). Arising in criollo breeds of cattle, several mutations in the gene exist that result in a truncated version of the protein to be synthesized (Porto-Neto et al., 2018). The gene has been introduced into Holsteins and is associated with reduced milk yield depression in the summer (Dikmen et al., 2014). Data from Puerto Rico indicate that slickhaired Holsteins are more fertile than Holsteins without the mutation (Ortiz-Colón et al., 2018).

There are also genetic effects on cellular resistance to elevated temperature. Embryos from Bos indicus breeds or the Romosinuano, a criollo breed, are more resistant to deleterious effects of heat shock on development of cultured embryos (Paula-Lopes et al., 2003b; Hernández-Cerón et al., 2004; Eberhardt et al., 2009; Silva et al., 2013). Fertility of cows in the summer was higher when inseminations were performed with Gyr semen than when Holstein semen was used (Pegorer et al., 2007). One gene that contains mutations that increases cellular resistance to heat shock is HSPA1L, as indicated by studies with lymphocytes (Basiricò et al., 2011) and embryos (Ortega et al., 2016).

\section{Final Note}

The decision as to which strategies to implement to reduce effects of heat stress on fertility is not a simple one. Embryo transfer, for example, while effective at minimizing the summer decline in fertility, is also expensive and may not be economically-effective unless the cost is constrained. In addition, getting cows pregnant in the summer can have long-term negative consequences for the resultant calf. Pinedo and De Vries (2017) have demonstrated that cows conceived in summer were older at first calving, had lower odds of surviving for a second calving, longer intervals from calving to first breeding and conception, and lower milk yield than cows conceived in winter. Thus, in some cases, non-uniform or seasonal calving may be the most profitable strategy. Genetic strategies that increase thermotolerance of the cow population are also desirable because, among other reasons, effects are permanent for that animal and extend to its offspring.

\section{Author contributions}

PJH: wrote and finalized the paper.

\section{Conflicts of interest}

The author declares no conflicts of interest.

\section{Funding}

Recent research by the author on this topic was funded by the Southeast Milk Checkoff Program and by the L.E. "Red" Larson Endowment.

\section{References}

Armengol-Gelonch R, M allo J M, Ponté D, J imenez A, Valenza A, Souza AH. 2017. Impact of phase of the estrous cycle and season on LH surge profile and fertility in dairy cows treated with different GnRH analogs (gonadorelin vs. buserelin). Theriogenology, 91:121-126.

Aréchiga CF, Staples CR, McDowell LR, Hansen PJ. 1998. Effects of timed insemination and supplemental $\beta$-carotene on reproduction and milk yield of dairy cows under heat stress. J Dairy Sci, 81:390-402.

Baruselli P S, F erreira R M, S ales J N, G imenes L U, Sá F ilho MF, Martins C M, R odrigues C A, B ó G A. 2011. Timed embryo transfer programs for management of donor and recipient cattle. Theriogenology, 76:15831593.

Badinga L, C ollier R J, T hatcher WW, Wi lcox C J. 1985 Effects of climatic and management factors on conception rate of dairy cattle in subtropical environment. J Dairy Sci, 68:78-85.

Basiricò L, Morera P, Primi V, Lacetera N, Nardone A, B ernabucci U . 2011. Cellular thermotolerance is associated with heat shock protein 70.1 genetic polymorphisms in Holstein lactating cows. Cell Stress Chaperones, 16:441-448.

Biggers B G, Geisert R D, Wetteman R P, B uchanan DS. 1987. Effect of heat stress on early embryonic development in the beef cow. J Anim Sci, 64:1512-1518.

Block J, Hansen PJ. 2007. Interaction between season and culture with insulin-like growth factor-1 on survival of in vitro produced embryos following transfer to lactating dairy cows. Theriogenology, 67:1518-1529.

Carvalho PD, Santos VG, Giordano JO, Wiltbank MC, Fricke P M. 2018. Development of fertility programs to achieve high 21-day pregnancy rates in high-producing dairy cows. Theriogenology, 114:165-172.

Cavallari de Castro F, Leal, CLV, Roth, Z, Hansen PJ. 2019. Effects of melatonin on production of reactive oxygen species and developmental competence of bovine oocytes exposed to heat shock and oxidative stress during in vitro maturation. Zygote, 27:180-186.

Chebel R C, D emétrio D G, Metzger J. 2008. Factors affecting success of embryo collection and transfer in large dairy herds. Theriogenology, 69:98-106.

Dahl GE, Tao S, Laporta J. 2017. Late gestation heat stress of dairy cattle programs dam and daughter milk production. J Anim Sci, 95:5701-5710.

de Castro e Paula LA, Hansen PJ. 2008. Modification of actions of heat shock on development and apoptosis of cultured preimplantation bovine embryos by oxygen concentration and dithiothreitol. Mol Reprod Dev, 75:1338-1350.

Dikmen S, Cole J B, Null DJ, Hansen PJ. 2012. Heritability of rectal temperature and genetic correlations with production and reproduction traits in dairy cattle. J Dairy Sci, 95:3401-3405.

Dikmen S, K han F A, H uson H J, So nstegard T S, 
Moss JI, Dahl GE, Hansen PJ. 2014. The SLICK hair locus derived from Senepol cattle confers thermotolerance to intensively managed lactating Holstein cows. J Dairy Sci, 97:5508-5520.

Drost M, Ambrose JD, Thatcher MJ, Cantrell CK, Wolfsdorf KE, Hasler JF, Thatcher WW. 1999. Conception rates after artificial insemination or embryo transfer in lactating dairy cows during summer in Florida. Theriogenology, 52:1161-1167.

Ealy AD, Drost M, Hansen PJ. 1993. Developmental changes in embryonic resistance to adverse effects of maternal heat stress in cows. J Dairy Sci, 76:2899-2905. Ealy AD, Aréchiga CF, Bray DR, Risco CA, Hansen PJ. 1994. Effectiveness of short-term cooling and vitamin $\mathrm{E}$ for alleviation of infertility induced by heat stress in dairy cows. J Dairy Sci, 77:3601-3607.

Ealy AD, Howell JL, Monterroso VH, Arechiga CF, Hansen PJ. 1995. Developmental changes in sensitivity of bovine embryos to heat shock and use of antioxidants as thermoprotectants. J Anim Sci, 73:1401 -1407.

Eberhardt BG, Satrapa RA, Capinzaiki CR, Trinca LA, Barros CM. 2009. Influence of the breed of bull (Bos taurus indicus vs. Bos taurus taurus) and the breed of cow (Bos taurus indicus, Bos taurus taurus and crossbred) on the resistance of bovine embryos to heat. Anim Reprod Sci, 114:54-61.

Edwards JL, Ealy AD, Monterroso VH, Hansen PJ. 1997. Ontogeny of temperature-regulated heat shock protein 70 synthesis in preimplantation bovine embryos, Mol Reprod Dev, 48: 25-33.

El-Tarabany MS, El-Tarabany AA. 2015. Impact of maternal heat stress at insemination on the subsequent reproductive performance of Holstein, Brown Swiss, and their crosses. Theriogenology, 84:1523-1529.

Ferraz PA, Burnley C, Karanja J, Viera-Neto A, Santos JE, Chebel RC, Galvão KN. 2016. Factors affecting the success of a large embryo transfer program in Holstein cattle in a commercial herd in the southeast region of the United States. Theriogenology, 86:18341841.

Ferreira RM, Ayres H, Chiaratti MR, Ferraz ML, Araújo AB, Rodrigues CA, Watanabe YF, Vireque AA, Joaquim DC, Smith LC, Meirelles FV, Baruselli PS. 2011. The low fertility of repeat-breeder cows during summer heat stress is related to a low oocyte competence to develop into blastocysts. J Dairy Sci, 94:2383-2392.

Flamenbaum I, Galon N. 2010. Management of heat stress to improve fertility in dairy cows in Israel. $J$ Reprod Dev, 56 (Suppl):S36-41.

Friedman E, Voet H, Reznikov D, Dagoni I, Roth Z. 2011. Induction of successive follicular waves by gonadotropin-releasing hormone and prostaglandin $F_{2 \alpha}$ to improve fertility of high-producing cows during the summer and autumn. J Dairy Sci, 94:2393-2402.

Friedman E, Roth Z, Voet H, Lavon Y, Wolfenson D. 2012. Progesterone supplementation postinsemination improves fertility of cooled dairy cows during the summer. J Dairy Sci, 95:3092-3099.

García-Ispierto I, Abdelfatah A, López-Gatius F. 2013. Melatonin treatment at dry-off improves reproductive performance postpartum in high-producing dairy cows under heat stress conditions. Reprod Domest Anim, 48: 577-583.
García-Ispierto I, López-Gatius F, Santolaria P, Yániz JL, Nogareda C, López-Béjar M, De Rensis F. 2006. Relationship between heat stress during the periimplantation period and early fetal loss in dairy cattle. Theriogenology, 65:799-807.

García-Ispierto I, De Rensis F, Pérez-Salas JA, Nunes JM, Pradés B, Serrano-Pérez B, López-Gatius F. 2019. The GnRH analogue dephereline given in a fixed-time AI protocol improves ovulation and embryo survival in dairy cows. Res Vet Sci, 122:170-174.

Gilad E, Meidan R, Berman A, Graber Y, Wolfenson D. 1993. Effect of tonic and GnRH-induced gonadotrophin secretion in relation to concentration of oestradiol in plasma of cyclic cows. J Reprod Fertil, 99:315-321.

Graf A, Krebs S, Zakhartchenko V, Schwalb B, Blum H, Wolf E. 2014. Fine mapping of genome activation in bovine embryos by RNA sequencing. Proc Natl Acad Sci USA, 111:4139-4144.

Gwazdauskas FC, Thatcher WW, Wilcox CJ. 1973. Physiological, environmental, and hormonal factors at insemination which may affect conception. J Dairy Sci, 56:873-877.

Gwazdauskas FC, Thatcher WW, Kiddy CA, Paape MJ, Wilcox CJ. 1981. Hormonal patterns during heat stress following PGF2 $\alpha$-tham salt induced luteal regression in heifers. Theriogenology, 16:271-285.

Hackbart KS, Ferreira RM, Dietsche AA, Socha MT, Shaver RD, Wiltbank MC, Fricke PM. 2010. Effect of dietary organic zinc, manganese, copper, and cobalt supplementation on milk production, follicular growth, embryo quality, and tissue mineral concentrations in dairy cows. J Anim Sci, 88:3856-3870.

Hansen PJ, Block J. 2004. Towards an embryocentric world: the current and potential uses of embryo technologies in dairy production. Reprod Fertil Dev, 16:1-14.

Hansen PJ. 2013a. Antecedents of mammalian fertility: Lessons from the heat-stressed cow regarding the importance of oocyte competence for fertilization and embryonic development. Anim Frontiers, 3: 34-28.

Hansen PJ. 2013b. Cellular and molecular basis of therapies to ameliorate effects of heat stress on embryonic development in cattle. Anim Reprod, 10: 322-333.

Hansen PJ. 2017. Physiological approaches to improving fertility during heat stress. In Large Herd Dairy Management, $3^{\text {rd }}$. ed., Beede, D.K. (ed.), American Dairy Science Assn, Champaign-Urbana, Illinois, chapter 7-24.

Her E, Wolfenson D, Flamenbaum I, Folman Y, Kaim M, Berman A. 1988. Thermal, productive, and reproductive responses of high yielding cows exposed to short-term cooling in summer. J Dairy Sci, 71:1085 1092.

Hernández-Cerón J, Chase CC Jr, Hansen PJ. 2004. Differences in heat tolerance between preimplantation embryos from Brahman, Romosinuano, and Angus Breeds. J Dairy Sci, 87:53-58

Howell JL, Fuquay JW, Smith AE. 1994. Corpus luteum growth and function in lactating Holstein cows during spring and summer. J Dairy Sci, 77:735-739.

Ispada J, Rodrigues TA, Risolia PHB, Lima RS, Gonçalves DR, Rettori D, Nichi M, Feitosa WB, 
Paula-Lopes FF. 2018. Astaxanthin counteracts the effects of heat shock on the maturation of bovine oocytes. Reprod Fertil Dev, 30:1169-1179.

Lamp O, Derno M, Otten W, Mielenz M, Nürnberg G, Kuhla B. 2015. Metabolic heat stress adaption in transition cows: differences in macronutrient oxidation between late-gestating and early-lactating German Holstein dairy cows. PLoS One, 10:e0125264.

Lawrence JL, Payton RR, Godkin JD, Saxton AM, Schrick FN, Edwards JL. 2004. Retinol improves development of bovine oocytes compromised by heat stress during maturation. J Dairy Sci, 87:2449-2454.

López-Gatius F, Hunter R. 2017. Clinical relevance of pre-ovulatory follicular temperature in heat-stressed lactating dairy cows. Reprod Domest Anim, 52:366-370. López-Gatius F, Hunter RHF. 2019a. Pre-ovulatory follicular cooling correlates positively with the potential for pregnancy in dairy cows: Implications for human IVF. J Gynecol Obstet Hum Reprod, 48:419-422.

López-Gatius F, Hunter RHF. 2019b. Pre-ovulatory follicular temperature in bi-ovular cows. J Reprod Dev, 65:191-194.

López-Gatius F, López-Béjar M, Fenech M, Hunter RH. 2005b. Ovulation failure and double ovulation in dairy cattle: risk factors and effects. Theriogenology, 63:1298-307.

López-Gatius F, Santolaria P, Martino A, Delétang F, De Rensis F. 2005c. The effects of GnRH treatment at the time of $\mathrm{AI}$ and 12 days later on reproductive performance of high producing dairy cows during the warm season in northeastern Spain. Theriogenology, 65:820-830.

López-Gatius F, Santolaria P, Mundet I, Yániz JL. 2005a. Walking activity at estrus and subsequent fertility in dairy cows. Theriogenology, 63:1419-1429.

Loureiro B, Bonilla L, Block J, Fear JM, Bonilla AQ, Hansen PJ. 2009. Colony-stimulating factor 2 (CSF-2) improves development and posttransfer survival of bovine embryos produced in vitro. Endocrinology, 150:5046-5054.

Mendonça LGD, Mantelo FM, Stevenson JS. 2017. Fertility of lactating dairy cows treated with gonadotropin-releasing hormone at AI, 5 days after AI, or both, during summer heat stress. Theriogenology, 91:9-16.

Nabenishi H, Ohta H, Nishimoto T, Morita T, Ashizawa K, Tsuzuki Y. 2012. The effects of cysteine addition during in vitro maturation on the developmental competence, ROS, GSH and apoptosis level of bovine oocytes exposed to heat stress. Zygote 20:249-259.

Nebel RL, Jobst SM, Dranfield MBG, Pandolfi SM, Bailey, TL. 1997. Use of radio frequency data communication system, HeatWatch ${ }^{\circledR}$, to describe behavioral estrus in dairy cattle. J Dairy Sci. 80 (Suppl. 1):179 (Abstract).

Nguyen TTT, Bowman PJ, Haile-Mariam M, Pryce JE, Hayes BJ. 2016. Genomic selection for tolerance to heat stress in Australian dairy cattle. J Dairy Sci, 99:2849-2862.

Ortega MS, Rocha-Frigoni NAS, Mingoti GZ, Roth Z, Hansen PJ, 2016. Modification of embryonic resistance to heat shock in cattle by melatonin and genetic variation in HSPA1L. J Dairy Sci, 99:9152-9164.

Ortiz-Colón G, Fain SJ, Parés IK, CurbeloRodríguez J, Jiménez-Cabán E, Pagán-Morales $M$, Gould WA. 2018. Assessing climate vulnerabilities and adaptive strategies for resilient beef and dairy operations in the tropics. Climate Change, 146:47-58.

Paula-Lopes FF, Chase CC Jr, Al-Katanani YM, Krininger CE III, Rivera RM, Tekin S, Majewski AC, Ocon OM, Olson TA, Hansen PJ. 2003b. Genetic divergence in cellular resistance to heat shock in cattle: Differences between breeds developed in temperate versus hot climates in responses of preimplantation embryos, reproductive tract tissues and lymphocytes to increased culture temperatures. Reproduction, 125:285-294.

Paula-Lopes FF, Al-Katanani YM, Majewski AC, Mc Dowell LR, Hansen PJ. 2003a. Manipulation of antioxidant status fails to improve fertility of lactating cows or survival of heat-shocked embryos. J Dairy Sci, 86:2343 -2351.

Pegorer MF, Vasconcelos JL, Trinca LA, Hansen PJ, Barros CM. 2007. Influence of sire and sire breed (Gyr versus Holstein) on establishment of pregnancy and embryonic loss in lactating Holstein cows during summer heat stress. Theriogenology, 67:692-697.

Pereira MH, Rodrigues AD, Martins T, Oliveira WV, Silveira PS, Wiltbank MC, Vasconcelos JL. 2013. Timed artificial insemination programs during the summer in lactating dairy cows: comparison of the 5-d Cosynch protocol with an estrogen/progesterone-based protocol. J Dairy Sci, 96:6904-6914.

Pinedo PJ, De Vries A. 2017. Season of conception is associated with future survival, fertility, and milk yield of Holstein cows. J Dairy Sci, 100:6631-6639.

Porto-Neto LR, Bickhart DM, Landaeta-Hernandez AJ, Utsunomiya YT, Pagan M, Jimenez E, Hansen PJ, Dikmen S, Schroeder SG, Kim ES, Sun J, Crespo E, Amati N, Cole JB, Null DJ, Garcia JF, Reverter A, Barendse W, Sonstegard TS. 2018. Convergent evolution of slick coat in cattle through truncation mutations in the prolactin receptor. Front Genet, 9:57.

Putney DJ, Drost M, Thatcher WW. 1988a. Embryonic development in superovulated dairy cattle exposed to elevated ambient temperatures between Days 1 to 7 post insemination. Theriogenology, 30:195-209.

Putney DJ, Drost M, Thatcher WW. 1989b. Influence of summer heat stress on pregnancy rates of lactating dairy cattle following embryo transfer or artificial insemination. Theriogenology, 31:765-778.

Putney DJ, Mullins S, Thatcher WW, Drost M, Gross TS. 1989a. Embryonic development in superovulated dairy cattle exposed to elevated ambient temperatures between the onset of estrus and insemination. Anim Reprod Sci, 19:37-51.

Putney DJ, Thatcher WW, Drost M, Wright JM, DeLorenzo MA. 1988b. Influence of environmental temperature on reproductive performance of bovine embryo donors and recipients in the southwest region of the United States. Theriogenology, 30:905-922.

Richards JI. 1985. Effect of high daytime temperatures on the intake and utilization of water in lactating Friesian cows. Trop Anim Health Prod, 17:209-217. 
Rocha de Zouza, F, Campos CC, Marques da Silva NA, dos Santos RM. 2016. Influence of seasonality, timing of insemination and rectal temperature on conception rate of crossbred dairy cows. Semina: Ciências Agrárias, Londrina, 37:155-162.

Rodrigues TA, Tuna KM, Alli AA, Tribulo P, Hansen PJ, Koh J, Paula-Lopes FF. 2019. Follicular fluid exosomes act on the bovine oocyte to improve oocyte competence to support development and survival to heat shock. Reprod Fertil Dev, 31:888-897.

Roth Z. 2017. Effect of heat stress on reproduction in dairy cows: insights into the cellular and molecular responses of the oocyte. Annu Rev Anim Biosci, 5:151-170. Roth Z, Arav A, Bor A, Zeron Y, Braw-Tal R, Wolfenson D. 2001b. Improvement of quality of oocytes collected in the autumn by enhanced removal of impaired follicles from previously heat-stressed cows. Reproduction, 122:737-744.

Roth Z, Arav A, Braw-Tai R, Bor A, Wolfenson D. 2002. Effect of treatment with follicle-stimulating hormone or bovine somatotropin on the quality of oocytes aspirated in the autumn from previously heatstressed cows. J Dairy Sci, 85:1398-1405.

Roth Z, Meidan R, Braw-Tal R, Wolfenson D. 2000. Immediate and delayed effects of heat stress on follicular development and its association with plasma FSH and inhibin concentration in cows. J Reprod Fertil, 120:83-90.

Roth Z, Meidan R, Shaham-Albalancy A, Braw-Tal R, Wolfenson D. 2001a. Delayed effect of heat stress on steroid production in medium-sized and preovulatory bovine follicles. Reproduction, 121:745-751.

Sakatani M, Alvarez NV, Takahashi M, Hansen PJ. 2012. Consequences of physiological heat shock beginning at the zygote stage on embryonic development and expression of stress response genes in cattle. J Dairy Sci, 95:3080-3091.

Sakatani M, Kobayashi S, Takahashi M. 2004. Effects of heat shock on in vitro development and intracellular oxidative state of bovine preimplantation embryos. Mol Reprod Dev, 67:77-82.

Sakatani M, Yamanaka K, Kobayashi S, Takahashi M. 2008. Heat shock-derived reactive oxygen species induce embryonic mortality in in vitro early stage bovine embryos. J Reprod Dev, 54:496-501.

Santolaria P, López-Gatius F, García-Ispierto I, Bech-Sàbat G, Angulo E, Carretero T, SánchezNadal JA, Yániz J. 2010. Effects of cumulative stressful and acute variation episodes of farm climate conditions on late embryo/early fetal loss in high producing dairy cows. Int J Biometeorol, 54:93-98.

Sartori R, Sartor-Bergfelt R, Mertens SA, Guenther JN, Parrish JJ, Wiltbank, MC. 2002. Fertilization and early embryonic development in heifers and lactating cows in summer and lactating and dry cows in winter. $J$ Dairy Sci, 85:2803-2812.

Skibiel AL, Peñagaricano F, Amorín R, Ahmed BM, Dahl GE, Laporta J. 2018. In utero heat stress alters the offspring epigenome. Sci Rep, 8:14609.

Shabankareh HK, Zandi M, Ganjali M. 2010. First service pregnancy rates following post-AI use of HCG in Ovsynch and Heatsynch programmes in lactating dairy cows. Reprod Domest Anim, 45:711-716.
Silva CF, Sartorelli ES, Castilho AC, Satrapa RA, Puelker RZ, Razza EM, Ticianelli JS, Eduardo HP, Loureiro B, Barros CM. 2013. Effects of heat stress on development, quality and survival of Bos indicus and Bos taurus embryos produced in vitro. Theriogenology, 79:351-357.

Stewart BM, Block J, Morelli P, Navarette AE, Amstalden M, Bonilla L, Hansen PJ, Bilby TR. 2011. Efficacy of embryo transfer in lactating dairy cows during summer using fresh or vitrified embryos produced in vitro with sex-sorted semen. J Dairy Sci, 94:3437-3445.

Stott GH, Wiersma F. 1976. Short term thermal relief for improved fertility in dairy cattle during hot weather. Int J Biometeorol, 20:344-350.

Thatcher WW, Collier RJ. 1986. Effects of climate on bovine reproduction. In: Current Therapy in Theriogenology 2. (D. A. Morrow, ed.), W. B. Saunders, Philadelphia pp. 301-309.

Torres-Júnior JR de S, Pires M de FA Pires, de Sá WF, Ferreira A de M, Viana JH, Camargo LS, Ramos AA, Folhadella IM, Polisseni J, de Freitas C, Clemente CA, de Sá Filho MF, Paula-Lopes FF, Baruselli PS. 2008. Effect of maternal heat-stress on follicular growth and oocyte competence in Bos indicus cattle. Theriogenology, 69:155-166.

Trout JP, McDowell LR, Hansen PJ. 1998. Characteristics of the estrous cycle and antioxidant status of lactating Holstein cows exposed to heat stress. J Dairy Sci, 81:1244-1250.

Vasconcelos JL, Jardina DT, Sá Filho OG, Aragon FL, Veras MB. 2011. Comparison of progesterone-based protocols with gonadotropin-releasing hormone or estradiol benzoate for timed artificial insemination or embryo transfer in lactating dairy cows. Theriogenology, 75:1153-1160.

Voelz BE, Rocha L, Scortegagna F, Stevenson JS, Mendonça LGD. 2016. Treatment of lactating dairy cows with gonadotropin-releasing hormone before first insemination during summer heat stress. J Dairy Sci, 99:7612-7623.

Wilson SJ, Marion RS, Spain JN, Spiers DE, Keisler DH, Lucy MC. 1998. Effects of controlled heat stress on ovarian function of dairy cattle. 1. Lactating cows. $J$ Dairy Sci, 81:2124-2131.

Wolfenson D, Flamenbaum I, Berman A. 1988. Hyperthermia and body energy store effects on estrous behavior, conception rate, and corpus luteum function in dairy cows. J Dairy Sci, 71:3497-3504.

Wolfenson D, Thatcher WW, Badinga L, Savio JD, Meidan R, Lew BJ, Braw-Tal R, Berman A. 1995. Effect of heat stress on follicular development during the estrous cycle in lactating dairy cattle. Biol Reprod, 52:1106-1113.

Wolff LK, Monty DE, Jr. 1974. Physiologic response to intense summer heat and its effect on the estrous cycle of nonlactating and lactating Holstein-Friesian cows in Arizona. Am J Vet Res, 35:187-192.

Zolini AM, Ortiz WG, Estrada-Cortes E, Ortega MS, Dikmen S, Sosa F, Giordano JO, Hansen PJ. 2019. Interactions of human chorionic gonadotropin with genotype and parity on fertility responses of lactating dairy cows. J Dairy Sci, 102:846-856. 